\title{
Distribution of crickets (Subfamily: Phalangopsinae) in caves of Baratang Island, Andaman and Nicobar Islands, India
}

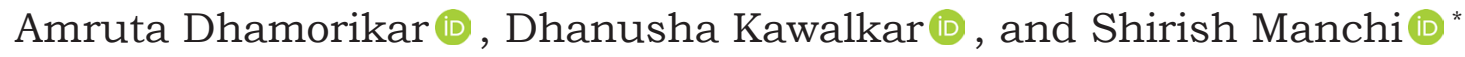 \\ Division of Conservation Ecology, Sálim Ali Centre for Ornithology and Natural History, Anaikatty Post, Coimbatore, Tamil Nadu, India
}

\begin{abstract}
Cave-dwelling organisms share different ecological and evolutionary relationships with caves. Based on these interactions, they are categorized as troglobites, troglophiles, and trogloxenes. In India, caves are meagerly explored, and thus cave study is in its infancy in India. Through the present study, we attempted to understand and model the distribution of crickets (Family Phalangopsidae), a critical group of insects - being the primary consumers in the cave ecosystems. We sampled seven caves using belt transects $\left(N=184\right.$; total area covered $\left.=1294.9 \mathrm{~m}^{2}\right)$ with $1 \mathrm{~m}$ width. During the survey, we encountered 818 individual crickets ( $116.85 \pm 47.16$ SD per cave). Of these, $87.7 \%$ encounters were on walls, $7.09 \%$ were on the ceiling, and $5.13 \%$ were on the cave floor. We used the Single-species Multi-season occupancy model to calculate the overall, zonewise, and cave-specific occupancy. Cricket occupancy in Baratang caves is seasonal and highly zonal, with detectability $\leq 1$. The cave with less distinct zones has more consistent occupancies and zero chances of extinction and colonization. Hence, these caves serve as suitable habitat for the source population. A negative correlation of cave morphometric features (cave volume, wall surface area, and floor surface area), and density of crickets $(p<0.05)$, might need further validation. The study shows the need for detailed studies regarding cricket taxonomy and ecology towards establishing the conservation importance of the species and their habitat in the islands.
\end{abstract}

Keywords: $\quad$ cave fauna, cave zones, occupancy, subterranean ecosystem, species distribution

Received 26 July 2020; Revised 22 October 2020; Accepted 23 October 2020

Citation: Dhamorikar A., Kawalkar D. and Manchi S., 2020. Distribution of crickets (Subfamily: Phalangopsinae) in caves of Baratang Island, Andaman and Nicobar Islands, India. International Journal of Speleology, 49 (3), 221-228. Tampa, FL (USA) ISSN 0392-6672 https://doi.org/10.5038/1827-806X.49.3.2341

\section{INTRODUCTION}

Based on their ecological and evolutionary relationships with caves, cave dwelling organisms can be separated into three categories - troglobites, troglophiles, and trogloxenes (Racovitza, 1907; Sket, 2008; Trajano \& Carvalho, 2017). Troglobites are the obligatory cave organisms that spend their entire life in caves. Troglophiles depend on caves for parts of their life but must exit the cave for critical biological functions. Trogloxenes are temporary visitors to caves (Romero, 2009; Moldovan et al., 2018).

Caves form a complex network of habitats with cracks, crevices, branches, and nodes of various sizes, most inaccessible to humans (Campbell et al., 2007). Variations in temperature, humidity, and intensity of light within caves create different microhabitats and attract temporary visitors, along with the permanently resident organisms. Terrestrial subterranean habitats are strongly zoned and defined based on the physical environment, especially the levels of light intensity, moisture, airflow, gas concentration (mainly $\mathrm{CO}_{2}$ ), and evaporative power of the air. Five such cave zones are the entrance, twilight, transition, deep, and stagnant air zones (Howarth, 1993; Moldovan et al., 2018). However, traditionally, according to the variations in the intensity of light, a cave is divided into Entrance, Twilight, and Dark zones (Biswas, 2009; Culver \& Pipan, 2009; Manenti et al., 2015). The entrance zone (EZ) or euphotic zone is the cave opening and immediate area where there is sufficient light for vascular plant life to grow. It supports the highest number of species as the mixing of epigean and hypogean (endogean) fauna occurs here. The twilight zone (TZ) or disphotic zone is the region with reduced/dim light and is not influenced directly by external factors. Beyond the twilight zone is total darkness where most obligatory cave animals occur. Microclimatic conditions in the dark zone (DZ) or aphotic zone are more or less constant, but periodically stagnates and gas concentrations, particularly carbon dioxide, become stressful (Howarth, 1993; Moldovan et al., 2018). According to Moldovan et al. (2018), zonation in caves provides a useful classification scheme to understand cave ecology. In the TZ, species diversity is low and mostly composed of strays from 
neighboring zones, surface animals seeking shelter, scavengers, and predators. It is increasingly evident that the $\mathrm{DZ}$ is a principal zone and the primary habitat of troglobitic, obligatory cave species, present in mesocavernous cracks and voids. In $\mathrm{TZ}$ and $\mathrm{DZ}$, minimum or no light results in limited or no primary energy production.

Crickets are hygrophilous insects that prefer highly humid environments like tropical rainforests (Biswas, 2009), thus found in large numbers in caves. Crickets of the family Rhaphidophoridae and Phalangopsidae are commonly known cavernicoles (Desutter-Grandcolas, 1998). These nocturnal feeders forage outside the caves and use caves as shelter, to breed, to digest food, and to defecate (Poulson et al., 1995; Lavoie et al., 2007). Most cave crickets are cavernicolous (Desutter-Grandcolas, 1998). Crickets gregariously overwinter on cave walls and ceilings in the twilight zone, both in temperate (Kozel et al., 2015; Lipovšek et al., 2016) and subtropical regions (Chelini et al., 2011). Crickets, including their feces and eggs, are a vital source of energy for other organisms in caves (Studier and Lavoie, 1990; Culver \& Pipan, 2009). Cave crickets subsidize several rare, endemic, and obligate cave-dwelling invertebrates through their active and regular transfer of organic matter from the surface to subsurface levels (Culver et al., 2000). Hence, these primary producers in many subterranean food webs are also the keystone species (Poulson \& Lavoie, 2000; Lavoie et al., 2007). The cave crickets have adapted to the DZ by significantly reducing their ability and propensity to jump since this behavior increases the predation rate (Howarth, 1983).

India is the second most diverse region, after the Neotropics, in terms of crickets of family Phalangopsidae (Desutter-Grandcolas \& Jaiswara, 2012). The country is known to harbor six cavernicolous cricket species, mainly from the Eastern and North-Eastern states of India. However, the cave fauna of Andaman and Nicobar Islands are still unexplored; thus, there are no previous records of any cave-dwelling cricket species from the islands. During several visits to the caves, we frequently encountered crickets. Knowing the primary ecological role of crickets in caves, we conducted a preliminary study to understand the population status and distribution pattern of crickets of the subfamily Phalangopsinae, family Phalangopsidae. We conducted the present study in select caves of the largest-known cave complex in the Andaman and Nicobar Islands of India. This study highlights the population and distribution of crickets within selected limestone caves. Further, we also attempted to understand the influence of structural variations between the morphology of caves and the cricket population living in them.

\section{METHODS}

\section{Study area}

The Andaman and Nicobar Islands are situated in the Bay of Bengal, towards south-east of the mainland India. The study area, viz., the Baratang Island $\left(12^{\circ} 05^{\circ}\right.$ $\left.\mathrm{N}, 92^{\circ} 45^{\circ} \mathrm{E}\right)$ is in the south of the Middle Andaman and north of South Andaman Islands (Fig. 1). It is a large island with an area of $251.85 \mathrm{~km}^{2}$. Baratang and Port Meadow groups, with the rock type of Mithakhari (Early to Middle Eocene), have interstratified massive and graded polymict conglomerates, massive crossstratified and graded sandstone, shales and thin coals (Allen et al., 2007; Bandopadhyay \& Carter, 2017). It has unique karstland vegetation (Mane et al., 2019), mostly dominated by Andaman tropical evergreen and Andaman semi-evergreen forests (Champion \& Seth, 2005). North and Middle Andaman experiences significant rainfall throughout the year $(8-536.5 \mathrm{~mm})$ with a short dry season between March and May (Hydromet Division, 2015).

The cave complex between Wraffter's Creek and Naya Dera on Baratang Island is spread across $0.77 \mathrm{~km}^{2}$ (Mane \& Manchi, 2017; 2018) and has more than 175 limestone caves (Sankaran, 2001; Manchi \& Sankaran, 2014; Bandopadhyay \& Carter, 2017), mostly inaccessible to people. We surveyed seven accessible caves to study the population and distribution of cave crickets. None of the study caves are gated or visited by tourists or locals. Out of the seven caves, six are occupied by bats, albeit in small numbers. Each cave was divided into transects of $1 \mathrm{~m}$ width with a maximum $2.5 \mathrm{~m}$ length (maximum accessible with minimum disturbance to the ecosystem) on both walls, amounting to total effort of 184 fixed-width transects with a range of 18 to 46 transects per cave $(26.2 \pm 11.2 \mathrm{SD})$. We divided the caves into three zones - entrance zone (EZ), twilight zone (TZ), and dark zone (DZ) based mainly on natural visibility of cave features by eye in the absence of artificial light (Biswas, 2009). We spent ten minutes at each transect to note the number and location (walls, ground, ceiling) of the crickets encountered in various zones. We conducted three repetitive surveys during the monsoon and post-monsoon seasons, i.e., June 2018, January, and February 2019, between 1000 hours and 1300 hours. We randomly noted temperature and relative humidity using handheld environment meter (Kestrel 3000) inside the caves during various visits. Using a standard survey method (Ford \& Cullingford, 1976; Kawalkar \& Manchi, 2020) and Leica Distometer S910, we recorded the morphometric measurements of the study caves to estimate the Cave Length (CL), Ceiling Surface Area (CSA), Wall Surface Area (WSA), Floor Area (FA) and Cave Volume (CV).

\section{Data Analysis}

We used Microsoft Excel (Ver. 2010) to perform the descriptive analysis (mean, standard deviation, range). We made comparisons of means (Student's $t$-test, $\mathrm{p}<0.05$ ), using XLSTAT Ver 20201.2 (Addinsoft, 2020). The density (D) of the crickets was estimated following $D=N / A^{*}$, where $N$ is the number of individuals encountered, and $\mathrm{A}$ is the total area surveyed. $\mathrm{Ab}=$ $\mathrm{N} / \mathrm{TN}$ calculated the abundance $(\mathrm{Ab})$, where $\mathrm{T}$ is a number of individuals encountered in a cave, and TN is the total number of individuals encountered in all caves (Macarthur, 1965). We performed a multiple regression fit to test the dependency of cricket abundance on morphometric parameters of caves. 


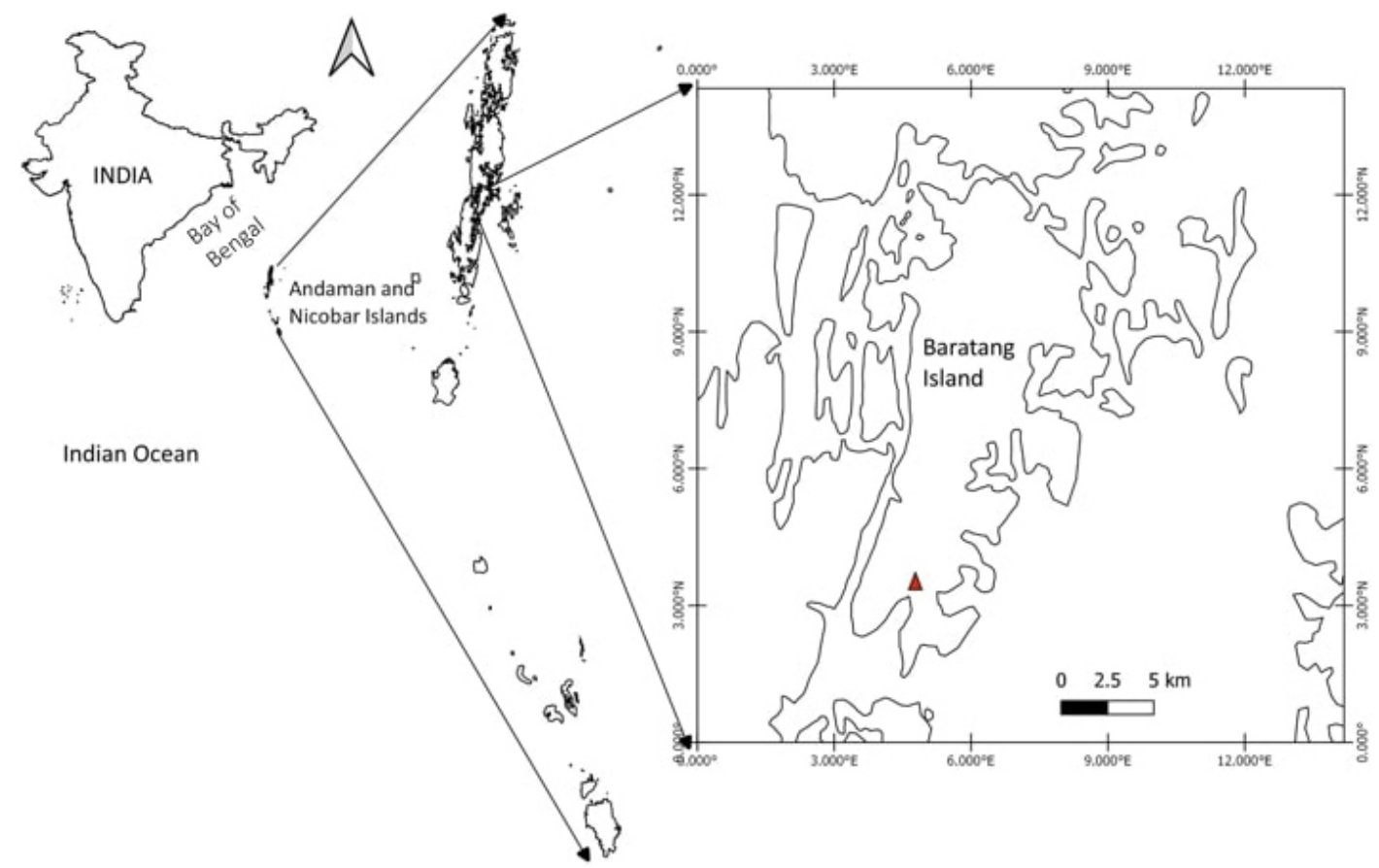

Fig. 1. Location of the Baratang cave complex on the Baratang Island of the Andaman and Nicobar Island.

Further, we used the Spearman Rank Correlation test to determine the nature of the correlation between cave morphometry variables and cricket abundance and density using XLSTAT Ver 20201.2 (Addinsoft, 2020) and using PRESENCE (Hines, 2006) ver. 12.7, we generated the Single-species Multi-season model for understanding the occupancy and distribution of crickets throughout the study caves (Mackenzie et al., 2002). Further, we treated the models for cave wise and cave zone wise occupancy (psi), colonization (gamma), extinction (epsilon), and detection probability (P). We considered the model with the lowest Akaike Information Criterion (AIC) value as the best fit.

\section{RESULTS}

\section{General Description of caves}

Baratang is the largest known karst diverse area in the Andaman group of Islands. It harbors limestone caves/voids ranging from $5 \mathrm{~m}$ to $220 \mathrm{~m}$ in length.
The limestone study caves on Baratang Island maintained nearly stable temperatures throughout the study period, with a slight variation of $2^{\circ} \mathrm{C}(23$ to $25^{\circ} \mathrm{C}$ ). Whereas, the relative humidity in the study caves varied considerably between $92 \%$ and $100 \%$. As part of a more extensive study, we prepared the maps and surveyed seven caves in the study area. The general description of the caves surveyed is in Table 1.

The seven caves surveyed during the study were of various Lengths, Volume, Floor Area, Wall Surface Area, and Ceiling Surface Area (Table 2). We encountered 818 individual crickets (Fig. 2; Range $=52-174)$ in all the seven caves with an average of $116.85 \pm 47.16$ (Mean \pm SD) crickets per cave. In 184 transects, covering a total area of $1294.9 \mathrm{~m}^{2}$, we encountered $5.41 \pm 4.9$ crickets per transect. Of the total 818 individuals encountered, $87.7 \%$ were on walls, $7.09 \%$ were on the ceiling, and $5.13 \%$ were on the cave floor.

Table 1. General description of the seven sampled caves.

\begin{tabular}{|l|c|c|c|c|c|c|c|c|c|c|}
\hline $\begin{array}{c}\text { Cave } \\
\text { No. }\end{array}$ & $\begin{array}{c}\text { Cricket } \\
\text { frequency }\end{array}$ & $\begin{array}{c}\text { Length } \\
(\mathbf{m})\end{array}$ & $\begin{array}{c}\text { Entrance } \\
\text { width }(\mathbf{m})\end{array}$ & $\begin{array}{c}\text { \# of } \\
\text { Entrances }\end{array}$ & $\mathbf{E Z}$ & $\mathbf{T Z}$ & $\mathbf{D Z}$ & Cave shape/type & $\begin{array}{c}\text { Structural } \\
\text { heterogeneity }\end{array}$ & $\begin{array}{c}\text { Presence of bat/ } \\
\text { bird guano }\end{array}$ \\
\hline 1 & $33.33 \pm 21.64$ & 16 & 1.5 & 1 & Yes & Yes & Yes & Horizontal & Low & Both \\
\hline 2 & $87.00 \pm 31.00$ & 11.2 & 1.3 & 1 & Yes & Yes & No & $\begin{array}{c}\text { Horizontal } \\
\text { fracture }\end{array}$ & Low & Bird only \\
\hline 3 & $53.67 \pm 21.48$ & 18.4 & 2 & 1 & Yes & Yes & Yes & Horizontal & Medium & Both \\
\hline 4 & $32.67 \pm 14.82$ & 20 & 1.2 & 1 & Yes & Yes & Yes & Horizontal & Medium & Both \\
\hline 5 & $21.33 \pm 13.91$ & 22.2 & 2.3 & 2 & Yes & Yes & Yes & Horizontal & Medium & Both \\
\hline 6 & $26.00 \pm 18.00$ & 40 & 0.8 & 2 & No & Yes & Yes & Hybrid & High & Both \\
\hline 7 & $56.33 \pm 4.78$ & 39.5 & 3.08 & 1 & Yes & Yes & Yes & Horizontal & High & Both \\
\hline
\end{tabular}

Table 2. Descriptive statistics of the morphometric parameters obtained from the seven sampled caves.

\begin{tabular}{|l|c|c|c|}
\hline \multicolumn{1}{|c|}{ Cave parameter (abbreviation) } & Units & Range & Mean \pm SD \\
\hline Cave Length (CL) & $\mathrm{m}$ & $11.2-40$ & $23.90 \pm 10.52$ \\
\hline Cave Volume (CV) & $\mathrm{m}^{3}$ & $6.1-804.1$ & $268.47 \pm 272.35$ \\
\hline Cave Floor Area (FA) & $\mathrm{m}^{2}$ & $18.5-95.8$ & $55.71 \pm 24.76$ \\
\hline Cave Wall Surface Area (WSA) & $\mathrm{m}^{2}$ & $55.9-729.3$ & $301.14 \pm 241.13$ \\
\hline Cave Ceiling Surface Area (CSA) & $\mathrm{m}^{2}$ & $2.5-114.3$ & $55.49 \pm 46.24$ \\
\hline
\end{tabular}


Among the surveyed caves, the highest density of crickets was 1.39 individuals per $\mathrm{m}^{2}$, and the lowest was $0.25 / \mathrm{m}^{2}$. The caves with the highest density also had the highest abundance and vice-a-versa. The abundance and density of the crickets varied significantly $(\mathrm{p}<0.05)$ between the zones. TZ had the highest density $\left(0.9 / \mathrm{m}^{2}\right)$ and lowest abundance (0.20) of crickets, as compared to the other two zones (Fig. 3).

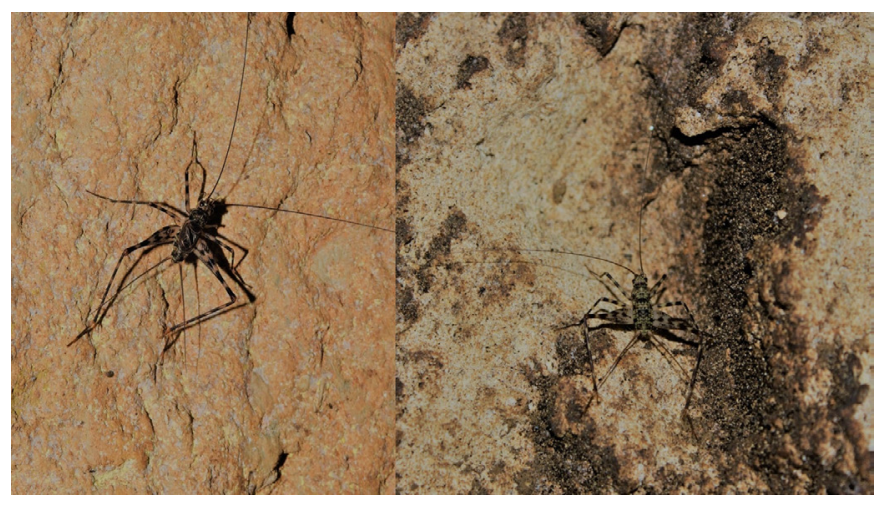

Fig. 2. Cave crickets (Subfamily: Phalangopsinae) from the study caves of Baratang Island, Andaman and Nicobar Islands.

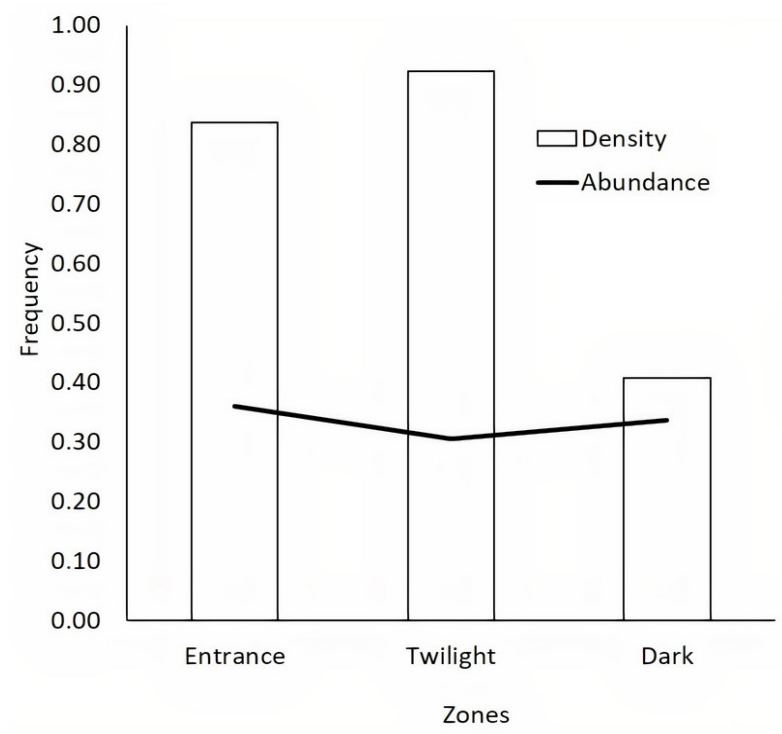

Fig. 3. Zone-wise average abundance and density of crickets.

Cave morphometric parameters and cricket density and abundance

When we regressed the density and abundance of crickets with the cave morphometric parameters, two predictors, the cave length $(\mathrm{CL})$ and the cave volume
(CV), were highly statistically significant with both abundance and density (Table 3). These two predictors accounted for the $89 \%$ variability with density $\left(R^{2}=0.89\right)$ and $79 \%$ with the abundance $\left(R^{2}=0.79\right)$. It indicates that $\mathrm{CL}$ and $\mathrm{CV}$ influence the abundance and density of cave crickets.

The Spearman Rank Correlation $(\rho)$ depicted a significant negative correlation between the cricket density and the cave morphometric parameters such as CV, WSA, and FA ( $<<0.05)$ (Table 4).

\section{Single-Species Multi-season Occupancy}

Overall and Zone wise

Crickets occupied all the sampled caves, with seasonal variations in their occupancy between dry (January and February) and wet season (June). Though crickets tend to occupy all caves and zones, with the detection probability $(\mathrm{p} \leq 1)$, the occupancy pattern of the crickets is highly zonal. EZ had the highest occupancy and colonization, and lowest extinction rates as compared to the $\mathrm{TZ}$ and $\mathrm{DZ}$ (Table 5).

\section{Cave specific model}

When we treated the data at each cave level, C1 and C2 had consistently high occupancies as compared to the other caves. There are seasonal variations in the occupancy, detection probability, colonization, and extinction in all the sampled caves (Table 6).

\section{DISCUSSION}

Crickets are one of the most common and abundant invertebrates found in the caves (Taylor et al., 2005; Fagan et al., 2007; Lavoie et al., 2007; Yoder et al., 2011; Weckerly, 2012), and the caves on Baratang Island are no exception. As documented by Hubbell \& Norton (1978), we also encountered most of the crickets clinging singly or in groups to the walls and ceilings inside caves, which might be to avoid predators or to find an optimal microclimate. Moreover, the nymphs of the crickets were seen on the ceiling of the study caves, where they may be less vulnerable to predators (Norton et al., 1975).

Based on the calculated average density of crickets $\left(0.64 / \mathrm{m}^{2}\right)$ in the caves on Baratang Island, we estimate around three cricket individuals in every $2 \mathrm{~m}^{2}$ of the sampled area inside the cave. Though various studies on cave crickets and their habitats

Table 3. Multi-regression model of the predictor variables (CL- Cave Length, CV- Cave Volume, CSA- Ceiling Surface Area, WSA- Wall Surface Area, FA- Floor Area) with abundance and density of crickets.

\begin{tabular}{|c|c|c|c|c|c|c|c|c|c|c|c|c|}
\hline & 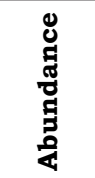 & $\begin{array}{l}\stackrel{D}{0} \\
\text { : } \\
0 \\
0\end{array}$ & 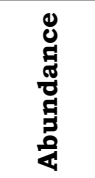 & $\begin{array}{l}\stackrel{D}{0} \\
\text { : } \\
\text { 。 } \\
\text { م }\end{array}$ & 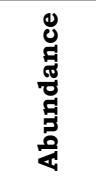 & 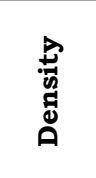 & 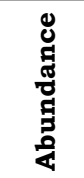 & 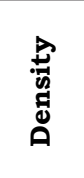 & 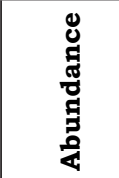 & 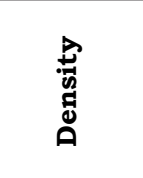 & 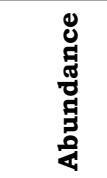 & 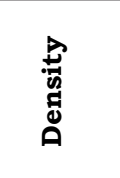 \\
\hline Source & \multicolumn{2}{|c|}{ Value } & \multicolumn{2}{|c|}{ Standard error } & \multicolumn{2}{|c|}{$\mathbf{t}$} & \multicolumn{2}{|c|}{$\operatorname{Pr}>|t|$} & \multicolumn{2}{|c|}{ Lower bound (95\%) } & \multicolumn{2}{|c|}{ Upper bound (95\%) } \\
\hline Intercept & 1.55 & 18.05 & 0.53 & 12.2 & 2.93 & 1.48 & 0.21 & 0.38 & -5.18 & -136.99 & 8.28 & 173.1 \\
\hline $\mathrm{CL}$ & 0.03 & 0.7 & 0.09 & 1.96 & 0.3 & 0.36 & 0.81 & 0.78 & -1.05 & -24.15 & 1.1 & 25.54 \\
\hline $\mathrm{CV}$ & 0.01 & 0.1 & 0.01 & 0.16 & 0.69 & 0.6 & 0.61 & 0.66 & -0.08 & -1.91 & 0.09 & 2.1 \\
\hline $\mathrm{CSA}$ & -0.01 & -0.09 & 0.01 & 0.29 & -0.74 & -0.31 & 0.59 & 0.81 & -0.17 & -3.8 & 0.15 & 3.62 \\
\hline WSA & -0.01 & -0.08 & 0.01 & 0.23 & -0.5 & -0.34 & 0.71 & 0.79 & -0.13 & -3.05 & 0.12 & 2.89 \\
\hline FA & -0.01 & -0.3 & 0.01 & 0.21 & -1.31 & -1.44 & 0.42 & 0.39 & -0.13 & -2.97 & 0.1 & 2.37 \\
\hline
\end{tabular}


Table 4. Spearman Rank Correlation tests for cricket abundance (A), density (D), cave length (CL), cave volume (CV), ceiling surface area (CSA), wall surface area (WSA) and floor area (FA) with significance values at $p<0.05$ (Note- values in bold represent the correlation and significance values $<0.05$ ).

\begin{tabular}{|l|c|c|c|c|c|c|c|}
\hline \multirow{2}{*}{ Variables } & $\mathbf{A}$ & $\mathbf{D}$ & $\mathbf{C L}$ & $\mathbf{C V}$ & $\mathbf{C S A}$ & WSA & FA \\
\cline { 2 - 7 } & $\begin{array}{c}\text { Statistical } \\
\text { value (p-value) }\end{array}$ & $\begin{array}{c}\text { Statistical } \\
\text { value (p-value) }\end{array}$ & $\begin{array}{c}\text { Statistical } \\
\text { value (p-value) }\end{array}$ & $\begin{array}{c}\text { Statistical } \\
\text { value (p-value) }\end{array}$ & $\begin{array}{c}\text { Statistical } \\
\text { value (p-value) }\end{array}$ & $\begin{array}{c}\text { Statistical } \\
\text { value (p-value) }\end{array}$ & $\begin{array}{c}\text { Statistical } \\
\text { value (p-value) }\end{array}$ \\
\hline A & $1(0)$ & & & & & & \\
\hline D & $0.607(0.167)$ & $1(0)$ & & & & & \\
\hline CL & $-0.143(0.783)$ & $-0.714(0.088)$ & $1(0)$ & & & & \\
\hline CV & $-0.357(0.444)$ & $\mathbf{- 0 . 9 2 9 ( 0 . 0 0 7 )}$ & $0.857(0.024)$ & $1(0)$ & & & \\
\hline CSA & $0.464(0.302)$ & $0.071(0.906)$ & $0.429(0.354)$ & $0.214(0.662)$ & $1(0)$ & & \\
\hline WSA & $-0.357(0.444)$ & $\mathbf{- 0 . 9 2 9 ( 0 . 0 0 7 )}$ & $0.857(0.024)$ & $1.000(<0.0001)$ & $0.214(0.662)$ & $1(0)$ & \\
\hline FA & $-0.357(0.444)$ & $\mathbf{- 0 . 9 2 9 ( 0 . 0 0 7 )}$ & $0.857(0.024)$ & $1.000(<0.0001)$ & $0.214(0.662)$ & $1.000(<0.0001)$ & $1(0)$ \\
\hline
\end{tabular}

Table 5. Overall and zone-wise occupancy model.

\begin{tabular}{|c|c|c|c|c|c|c|c|c|c|c|}
\hline & \multirow{2}{*}{ AIC } & \multirow{2}{*}{$\begin{array}{c}-2 \log \\
\text { (likelihood) }\end{array}$} & \multicolumn{3}{|c|}{ Occupancy across surveys (psi) } & \multirow{2}{*}{$\begin{array}{c}\text { Colonization } \\
\text { (gamma) }\end{array}$} & \multirow{2}{*}{$\begin{array}{c}\text { Extinction } \\
\text { (epsilon) }\end{array}$} & \multicolumn{3}{|c|}{$\begin{array}{c}\text { Detection Probability across } \\
\text { surveys (P) }\end{array}$} \\
\hline & & & 1 & 2 & 3 & & & 1 & 2 & 3 \\
\hline Overall & 758.81 & 750.81 & $0.65 \pm 0.03$ & $0.470 \pm 0.02$ & $0.44 \pm 0.02$ & $0.37 \pm 0.03$ & $0.48 \pm 0.03$ & $1.00 \pm 0.00$ & $1.00 \pm 0.00$ & $1.00 \pm 0.00$ \\
\hline Entrance zone (EZ) & 145.41 & 137.41 & $0.92 \pm 0.03$ & $0.47 \pm 0.06$ & $0.45 \pm 0.06$ & $0.42 \pm 0.09$ & $0.51 \pm 0.06$ & $1.00 \pm 0.00$ & $1.00 \pm 0.00$ & $1.00 \pm 0.00$ \\
\hline Twilight zone (TZ) & 150.29 & 142.29 & $1.00 \pm 0.00$ & $0.81 \pm 0.10$ & $0.85 \pm 0.06$ & $1.00 \pm 0.00$ & $0.18 \pm 0.10$ & $0.77 \pm 0.06$ & $0.77 \pm 0.06$ & $0.77 \pm 0.06$ \\
\hline Dark Zone (DZ) & 434.2 & 426.2 & $0.51 \pm 0.04$ & $0.374 \pm 0.03$ & $0.35 \pm 0.03$ & $0.31 \pm 0.04$ & $0.57 \pm 0.05$ & $1.00 \pm 0.00$ & $1.00 \pm 0.00$ & $1.00 \pm 0.00$ \\
\hline
\end{tabular}

Table 6. Cave-specific occupancy model.

\begin{tabular}{|c|c|c|c|c|c|c|c|}
\hline Cave & Survey & $-2 \log$ (likelihood) & AIC & Occupancy (psi) & $\begin{array}{l}\text { Colonization } \\
\text { (gamma) }\end{array}$ & $\begin{array}{c}\text { Extinction } \\
\text { (epsilon) }\end{array}$ & $\begin{array}{c}\text { Detection } \\
\text { probability (p) }\end{array}$ \\
\hline \multirow{3}{*}{$\mathrm{C} 1$} & 1 & 66 & 74 & $0.90 \pm 0.07$ & $00.0 \pm 0.00$ & $00.0 \pm 0.00$ & $0.73 \pm 0.06$ \\
\hline & 2 & & & $0.90 \pm 0.07$ & $00.0 \pm 0.00$ & $00.0 \pm 0.00$ & $0.73 \pm 0.06$ \\
\hline & 3 & & & $0.90 \pm 0.07$ & $00.0 \pm 0.00$ & $00.0 \pm 0.00$ & $0.73 \pm 0.06$ \\
\hline \multirow{3}{*}{$\mathrm{C} 2$} & 1 & 71.22 & 79.22 & $0.81 \pm 0.06$ & $1.00 \pm 0.00$ & $0.45 \pm 0.12$ & $0.81 \pm 0.06$ \\
\hline & 2 & & & $0.81 \pm 0.06$ & $1.00 \pm 0.00$ & $0.45 \pm 0.12$ & $0.81 \pm 0.06$ \\
\hline & 3 & & & $0.81 \pm 0.06$ & $1.00 \pm 0.00$ & $0.45 \pm 0.12$ & $0.81 \pm 0.06$ \\
\hline \multirow{3}{*}{ C3 } & 1 & 73.92 & 81.92 & $0.80 \pm 0.08$ & $0.33 \pm 0.12$ & $0.33 \pm 0.09$ & $1.00 \pm 0.00$ \\
\hline & 2 & & & $0.60 \pm 0.08$ & $0.33 \pm 0.12$ & $0.33 \pm 0.09$ & $1.00 \pm 0.00$ \\
\hline & 3 & & & $0.53 \pm 0.09$ & $0.33 \pm 0.12$ & $0.33 \pm 0.09$ & $1.00 \pm 0.00$ \\
\hline \multirow{3}{*}{$\mathrm{C} 4$} & 1 & 65.4 & 73.4 & $0.83 \pm 0.08$ & $0.50 \pm 0.13$ & $0.40 \pm 0.10$ & $1.00 \pm 0.00$ \\
\hline & 2 & & & $0.57 \pm 0.09$ & $0.50 \pm 0.13$ & $0.40 \pm 0.10$ & $1.00 \pm 0.00$ \\
\hline & 3 & & & $0.55 \pm 0.09$ & $0.50 \pm 0.13$ & $0.40 \pm 0.10$ & $1.00 \pm 0.00$ \\
\hline \multirow{3}{*}{$\mathrm{C} 5$} & 1 & 89.85 & 97.85 & $0.60 \pm 0.10$ & $0.30 \pm 0.09$ & $0.60 \pm 0.10$ & $1.00 \pm 0.00$ \\
\hline & 2 & & & $0.35 \pm 0.07$ & $0.30 \pm 0.09$ & $0.60 \pm 0.10$ & $1.00 \pm 0.00$ \\
\hline & 3 & & & $0.33 \pm 0.07$ & $0.30 \pm 0.09$ & $0.60 \pm 0.10$ & $1.00 \pm 0.00$ \\
\hline \multirow{3}{*}{ C6 } & 1 & 138.88 & 146.88 & $0.62 \pm 0.70$ & $0.56 \pm 1.09$ & $0.65 \pm 0.44$ & $0.48 \pm 0.60$ \\
\hline & 2 & & & $0.42 \pm 0.51$ & $0.56 \pm 1.09$ & $0.65 \pm 0.44$ & $0.48 \pm 0.60$ \\
\hline & 3 & & & $0.47 \pm 0.68$ & $0.56 \pm 1.09$ & $0.65 \pm 0.44$ & $0.48 \pm 0.60$ \\
\hline \multirow{3}{*}{$\mathrm{C} 7$} & 1 & 175.25 & 183.25 & $0.88 \pm 0.55$ & $0.52 \pm 0.23$ & $0.38 \pm 0.38$ & $0.88 \pm 0.54$ \\
\hline & 2 & & & $0.60 \pm 0.40$ & $0.52 \pm 0.23$ & $0.38 \pm 0.38$ & $0.88 \pm 0.54$ \\
\hline & 3 & & & $0.57 \pm 0.34$ & $0.52 \pm 0.23$ & $0.38 \pm 0.38$ & $0.88 \pm 0.54$ \\
\hline
\end{tabular}

explained some cave characters as part of the cricket habitat, the present study might be the first, considering cave morphometry as one of the critical habitat components, influencing the existence and population of the crickets in caves. Lavoie et al. (2007) documented that the crickets roost in small crevices and stay away from open spaces. This may be a possible explanation for the correlations between the cricket density and abundance and the cave morphometric parameters observed in the present study. High density and abundance of crickets were in the smallest and shortest cave (a crack type cave with $11.2 \mathrm{~m}$ length and $6.1 \mathrm{~m}^{3}$ volume), and lowest density and abundance were in one of the longest and largest caves surveyed $\left(39.5 \mathrm{~m}\right.$ length and $427 \mathrm{~m}^{3}$ volume). It confirms the negative correlation of these cave morphometric parameters with the population of crickets in the caves. The cricket population also depicted a similar relationship with the FA. Based on the relationship between the cave structure (CL and $\mathrm{CV}$ ) and cricket abundance and density, we understand that these parameters also affect the cricket occupancy. A study by Souza et al. (2020) on the invertebrates in Neotropical mountain quartzite 
caves described that the CL (cave extension) and presence of streams were the main factors determining the variation of species composition among caves. Furthermore, he concluded that the total richness and richness of troglobitic species in caves increased with CL. Though CL and CV affect cricket density and abundance, we understand that the microclimatic parameters might also be contributing factors.

In the cave-wise occupancy, unlike all other six caves, C1 does not depict any local extinction of crickets. It may be because this $16 \mathrm{~m}$ long cave has only two zones, EZ ( $\leq 2 \mathrm{~m}$ long) and DZ, which implies to low interaction between epigean and hypogean environments. The availability of more suitable breeding areas for crickets complements the behavior of the cave crickets. Further, we presume that $\mathrm{C} 1$ might act as the primary breeding site, as the cave has longer dark zone as compared to the entrance and twilight zones. Also, the presence of mud in the twilight and dark zones along with bird and bat guano can serve as breeding habitats for the crickets. This cave might also function as a nearest breeding site for most of the populations in this cave complex, or at least for the adjacent caves, to have the source population (Poulson et al., 1998), which can further disperse to the other nearby caves.

The cricket occupancy was highly zonal in the caves on Baratang Island. The $\mathrm{EZ}$ and $\mathrm{TZ}$ had the highest occupancy as compared to DZ. Crickets, the nocturnal foragers, are understood to utilize EZ and $\mathrm{TZ}$ primarily to roost during the light hours and also to assess the external conditions before exiting to forage after dusk. A study by Tobin et al. (2013) on the spatial and temporal changes in invertebrate assemblage structure from the entrance to the deepcave zone of a temperate marble cave documented that the physiological limitations of the organisms might result in higher trogloxenes diversity close to the entrance of caves. Some long-term biomonitoring studies (Hubbell \& Norton, 1978; Lavoie et al., 2007) documented that large populations of crickets of all sizes ready to exit the cave and forage, with predominant adults, were found in the EZ. It supports our finding of high colonization and the low extinction of crickets in the TZ of Baratang caves. DZ, the cricket breeding habitat, is occupied consistently by breeding adults and the young ones. As they breed in DZ and spend the first part of their life in the dark, According to Howarth (1983), cave crickets and other jumping arthropods, have significantly reduced their ability and propensity to jump since this behavior is hazardous in total darkness. It supports the finding of the present study that the cricket occupancy is more in $\mathrm{EZ}$ and $\mathrm{TZ}$.

Lavoie et al. (2007) observed that roost counts of the cave crickets are higher in the evenings (18:00 hours) and lower in the early morning (06:00 hours) because of the nocturnal foraging outside the caves. Whereas, the present study with the observation timing was between 10:00 hours and 13:00 hours, depicted no significant variation in the abundance and density of crickets between all three zones. As we could not encounter any previous studies made during these timings, we presume that the crickets might disperse to all the zones after returning from foraging and then again aggregate in the $\mathrm{EZ}$ and $\mathrm{TZ}$ before coming out for foraging after sunset. However, this needs further exploration and confirmation. On the other hand, the EZ has shown high occupancy in the caves at Baratang during observational period (10:00 hours to 13:00 hours). It might be a result of the cave structure and the presence of microhabitats. According to some studies, locations where cave crickets reside are relatively stable with low temperature, high moisture, and dampness with complete darkness (Hobbs, 1992; Hill, 2003). These moisture-rich conditions with darkness are particularly true for the upper recesses and scallops in walls and bells in ceilings (of passages away from fast-moving desiccating air currents) where these crickets aggregate (Hazelton \& Hobbs, 2003) showcasing lower abundance visibility of the individuals. There might be fewer individuals detected in the $\mathrm{TZ}$ and $\mathrm{DZ}$ than what are present because of the complex structure of the caves, presence of speleothems, and other microhabitats for roosting of crickets. As per our observations in the caves of Baratang, the EZ is less structurally heterogeneous in comparison with $\mathrm{TZ}$ and $\mathrm{DZ}$, which might help in better detection of the cricket individuals here. Also, due to physiological requirements and microclimatic suitability, various species occupy their suitable zone (Lunghi et al., 2014), and seasonal changes in the microclimate of the caves result in variations in the faunal distribution (Lunghi et al., 2017). The heterogeneous microclimatic conditions result in abundant troglophile and trogloxene fauna in the EZ and $\mathrm{TZ}$ of the caves.

Apart from the numerical outputs, the regular presence of small-sized individuals of crickets in the DZ allowed us to presume that the cave crickets in the Andaman and Nicobar islands might be breeding round the year. However, further studies are required to understand more about cricket biology.

\section{CONCLUSION}

The present study concludes that the limestone caves of Baratang Island support a good population of crickets of the sub-family Phalangopsinae. They occupy a range of caves of different morphologies and are present in all the cave zones. Various factors influence the use of a particular zone or a microhabitat in a cave. While they were seen more in the EZ and $\mathrm{TZ}, \mathrm{DZ}$ also has a good number of individual crickets. Though, the crickets are distributed across the zones, unequal distribution indicates high zonal occupancy. Further, it can be entirely dependent on survey timings and cave structure in a particular zone, which needs further validation. It is also worth noting that the cave length and cave volume influence the most abundant invertebrate in the Baratang caves. There is a possibility that the adult crickets prefer EZ and $\mathrm{TZ}$, whereas the juveniles might be using $\mathrm{DZ}$ for better protection.

In India, especially in the Andaman and Nicobar Islands, no studies are available on cave crickets or 
on any other cave fauna. There is a need to initiate taxonomic studies for the Andaman cave crickets and other invertebrates. Detailed research regarding invertebrate taxonomy, distribution, population, and ecology is required to ascertain whether the cricket species encountered are new to science, endemic to the islands, and of any conservation importance. Based on this preliminary study, further research focus can be on the taxonomy and ecology of crickets, effects of microclimate on their distribution, breeding, roosting, and feeding behavior in caves of the Andaman Islands. These studies will help understand the role of crickets in caves of tropical islands, prioritization of caves/ species of conservation importance, and appropriate management of these tropical caves and the karst landscape.

\section{ACKNOWLEDGEMENTS}

We thank the Ministry of Environment, Forest and Climate Change for funding the Andaman Ediblenest Swiftlet conservation project. Under the habitat study aspect of the project, we conducted the present study. We are grateful to the Andaman and Nicobar Forest Department, for their active collaboration in the project and providing permissions to conduct the study on cave fauna in the region. We especially thank Divisional Forest Officers, Mayabunder (WL), and Baratang (Territorial) for the support extended towards the execution of the project fieldwork. We are indebted to Prathamesh Gurjarpadhye, Justin Sumit Kumar, Senthil Toppo, Saw Safarmi, Rajendar Lakra, and Senthi Kullu for their unconditional support during data collection.

Authorship statement: AD and SM together designed and directed the study. SM administered the work. AD collected the data, and DK carried out the simulations. $\mathrm{AD}$ and $\mathrm{DK}$ together carried out the data analysis and wrote the manuscript under the supervision of SM. SM has also contributed immensely while building and reviewing the manuscript.

\section{REFERENCES}

Addinsoft., 2020. XLSTAT statistical and data analysis solution. New York. https://www.xlstat.com

Allen, R., Carter, A. et al., 2007. New constraints on the sedimentation and uplift history of the AndamanNicobar Accretionary prism, South Andaman Island. In: Draut, A., Clift, P.D. \& Scholl, D.W. (Eds.) Formation and applications of the sedimentary record in arc collision zones. Geological Society of America, Special Paper, 436, 223-255.

https://doi.org/10.1130/2008.2436(11)

Bandopadhyay, P.C., and Carter, A., 2017. Introduction to the geography and geomorphology of the AndamanNicobar Islands. Geological Society, London, Memoirs, 47(1), 9-18. https://doi.org/10.1144/M47.2

Biswas, J., 2009. Kotumsar Cave biodiversity: a review of cavernicoles and their troglobiotic traits. Biodiversity Conservation, 19(1), 275-289. https://doi.org/10.1007/s 10531-009-9710-7

Campbell, G.E.H., Lowe, W.H., Fagan, W.F., 2007. Living in the branches: Population dynamics and ecological processes in dendritic networks. Ecology Letters, 10, 165-175.

https://doi.org/10.1111/j.1461-0248.2006.01007.x

Champion, H.G., Seth, S.K., 2005. A revised survey of the forest types of India. Natraj Publishers, Dehradun, 62-167 p.

Chelini, M., Willemart, R. H., Gnaspini, P., 2011. Caves as a winter refuge by a neotropical Harvestman (Arachnida, Opiliones). Journal of Insect Behaviour, 24, 393-398.

https:// doi.org/10.1007/s10905-011-9264-x

Culver, D.C., Pipan, T., 2009. The biology of caves and other subterranean habitats. Oxford University Press, New York. https://doi.org/10.15713/ins.mmj.3

Desutter-Grandcolas, L., Jaiswara, R., 2012. Phalangopsidae crickets from the Indian Region (Orthoptera, Grylloidea), with the descriptions of new taxa, diagnoses for genera, and a key to Indian genera. Zootaxa, 3444, 1-39.

https://doi.org/10.11646/zootaxa.3444.1.1

Fagan, W.F., Lutscher, F., Schneider, K., 2007. Population and community consequences of spatial subsidies derived from central-place foraging. The American Naturalist, 170(6), 902-915. https://doi.org/10.1086/522836

Ford, T.D., Cullingford, C.H.D., 1976. The Science of Speleology. Academic Press, London, New York.

Hazelton, M. C., Hobbs, H. H. III, 2003. Climatic effects on the population density of the salamander, Plethodon glutinosus (Green), in Coon-in-the-Crack Cave I, Carter County, Kentucky. Pholeos, 21(8), 16.

Hill, S.E., 2003. Examination of the movements of crickets in Laurel Cave, Carter County, Kentucky. Pholeos 21, 24-28.

Hines, J. E., 2006. PRESENCE 2.0 - Software to Estimate Patch Occupancy and Related Parameters. USGSPWRC, Laurel.

Hobbs, H.H. III., 1992. Caves and springs. In: Hackney, C.T., Adams, S.M., Martin, W.M. (Eds.) Biodiversity of the South-eastern United States: aquatic communities. Wiley, London, p. 59-131.

Howarth, F.G., 1983. Ecology of cave arthropods. Annual Review of Entomology, 28, 365-389.

https://doi.org/10.1146/annurev.en.28.010183.002053

Howarth, F.G., 1993. High-stress subterranean habitats and evolutionary change in cave-inhabiting arthropods. Ambient Nature, 142, S65-S77. https://doi.org/10.1086/285523

Hubbell, T.H., Norton, R.M., 1978. The systematics and biology of the cave-crickets of the North American tribe Hadenoecini (Orthoptera Saltatoria: Ensifera: Rhaphidophoridae: Dolichopodinae). Museum of Zoology, University of Michigan No. 56.

Hydromet Division IMD., 2015. Customized Rainfall Information System (CRIS) District: North and Middle Andaman. http://hydro.imd.gov.in [accessed: September 16, 2019].

Kawalkar, D., Manchi, S., 2020. Coastal caves on the Interview Island of Andaman Islands, India. Carbonates Evaporites, 35, 111. https://doi.org/10.1007/s13146-020-00646-w

Kozel, P., Novak, T., Klokočovnik,V., Lipovšek, S., 2015. Comparison of overwintering's in two harvestman species (Arachnida: Opiliones) in subterranean habitats. In: Abstracts of the 29 $9^{\text {th }}$ European Congress of Arachnology, Brno (CZ), 24-28 August 2015

Lavoie, K.H., Helf, K.L., Poulson, T.L., 2007. The biology and ecology of North American cave crickets. Journal of Cave and Karst Studies, 69(1), 114-134. 
Lipovšek, S., Novak, T., 2016. Autophagy in the fat body cells of the cave cricket Troglophilus neglectus Krauss, 1878 (Rhaphidophoridae, Saltatoria) during overwintering. Protoplasma, 253(2), 457-466.

https://doi.org/10.1007/s00709-015-0824-3

Lunghi, E., Manenti, R., Ficetola, G.F., 2014. Do cave features affect underground habitat exploitation by non-troglobite species? Acta Oecologica, 55, 29-35. https://doi.org/10.1016/j.actao.2013.11.003

Lunghi, E., Manenti, R., Ficetola, G.F., 2017. Cave features, seasonality and subterranean distribution of non-obligate cave dwellers. PeerJ, 5, e3169.

https://doi.org/10.7717/peerj.3169

Macarthur, R.H., 1965. Patterns of Species Diversity. Biological Reviews, 40(4), 510-533.

https://doi.org/10.1111/j.1469-185X.1965.tb00815.x

Mackenzie, D.I., Nichols, J.D., Lachman, G.B., Droege, S., Royle, A., Langtimm, C., 2002. Estimating site occupancy rates when detection probabilities are less than one. Ecology, 83(8), 2248-2255.

https://doi.org/10.1890/0012-9658(2002)083 [2248:ESORWD]2.0.CO;2

Manchi, S., Sankaran, R., 2014. Protection of the whitenest swiftlet Aerodramus fuciphagus in the Andaman. Oryx, 48(2), 213-217. https://doi.org/10.1017/S0030605311000603

Mane, A. M., Manchi, S. S., 2018. Civets in the limestone caves of Andaman Islands: notes on the distribution and natural history. Ambient Science, 5(1), 6-10. https://doi.org/10.21276/ambi.2018.05.1.ga02

Mane, A., Manchi, S., 2017. Roosting patterns of the Edible-Nest Swiftlet (Aerodramus fuciphagus) of the Andaman Islands: effects of lunar phase and breeding chronology. Emu - Austral Ornithology, 117(4), 325-332. https://doi.org/10.1080/01584197.2017.1336065

Mane, A., Prabakaran, N., Manchi, S., 2019. Floral diversity, composition, and recruitment on the karstland of Baratang Island, India. Ecological Complexity, 37, 47-54. https://doi.org/10.1016/j.ecocom.2018.11.002

Manenti, R., Lunghi, E., Ficetola, G.F., 2015. The distribution of cave twilight-zone spiders depends on microclimatic features and trophic supply. Invertebrate Biology, 134(3), 242-251. https://doi.org/10.1111/ivb.12092

Moldovan, O.T., Lubomir, K., Stuart, H. (Eds.), 2018. Cave ecology. Springer, Cham, 544 p. https:// doi.org/10.1007/978-3-319-98852-8

Norton, R.M., Kane, T.C., and Poulson, T.L., 1975, The ecology of a predaceous troglobitic beetle, Neaphaenops tellkampfi (Coleoptera: Carabidae, Trechinae) II. Adult seasonality, feeding, and recruitment: International Journal of Speleology, 7, 55-64. https://doi.org/10.5038/1827-806X.7.1.6

Poulson, T.L., Lavoie, K.H., 2000. The trophic basis of subsurface ecosystems. In: Wilkens $\mathrm{H}$, Culver DC, Humphreys WF (Eds) Ecosystems of the World, Vol. 30: Subterranean Ecosystems. Elsevier Academic Press, Amsterdam, p. 231-249.

Poulson, T.L., Lavoie, K.H., Helf, K., 1995. Longterm effects of weather on the cricket (Hadenoecus subterraneus, Orthoptera, Rhaphidophoridae) guano community in Mammoth Cave National Park. American Midland Naturalist, 134(2), 226-236.

https://doi.org/10.2307/2426293
Poulson, T.L., Lavoie, K.H., Helf, K., 1998. Cave crickets at Mammoth Cave National Park: Source and sink population dynamics. Journal of Cave and Karst Studies, 60(3), 181.

Racovitza, E., 1907. Essai sur les problèmes biospéologiques. Archives de Zoologie Expéri- Mentale et Générale, 4 a ser, (6), 371-488.

Romero, A., 2009. The evolutionary biology of cave organisms. In: Cave biology: Life in darkness. Cambridge University Press, Cambridge, 132 p.

https://doi.org/10.1017/CBO9780511596841

Sankaran, R., 2001. The status and conservation of the Edible-nest Swiftlet (Collocalia fuciphaga) in the Andaman and Nicobar Islands. Biological Conservation, 97(3), 283-294.

https://doi.org/10.1016/S0006-3207(00)00124-5

Sket, B., 2008. Can we agree on an ecological classification of subterranean animals? Journal of Natural History, 42(21-22), 1549-1563. https://doi.org/10.1080/00222930801995762

Souza, S.M., Iniesta, L.F.M., Ferreira, R.L., 2020. Invertebrates diversity in mountain Neotropical quartzite caves: which factors can influence the composition, richness, and distribution of the cave communities? Subterranean Biology, 33, 23-43. https://doi.org/10.3897/subtbiol.33.46444

Studier, E.H., Lavoie, K.H., 1990. Biology of Cave Crickets, Hadenoecus subterraneus, and camel crickets, Ceuthophilus stygius (Insecta: Orthoptera): Metabolism and water economies related to size and temperature. Comparative Biochemistry and Physiology, 95A (I), 157-161.

https://doi.org/10.1016/0300-9629(90)90025-N

Taylor, S.J., Krejca, J.K., Denight, M.L., 2005. Foraging range and habitat use of Ceuthophilus secretus (Orthoptera: Rhaphidophoridae), a key trogloxene in central Texas cave communities. The American Midland Naturalist, 154(1), 97-114. https://doi.org/10.1674/0003-0031(2005)154 [0097:FRAHUO]2.0.CO;2

Tobin, B.W., Hutchins, B.T., Schwartz, B.F., 2013. Spatial and temporal changes in invertebrate assemblage structure from the entrance to deep-cave zone of a temperate marble cave. International Journal of Speleology, 42(3), 203-214.

https://doi.org/10.5038/1827-806X.42.3.4

Trajano, E., de Carvalho, M.R., 2017. Towards a biologically meaningful classification of subterranean organisms: a critical analysis of the Schiner-Racovitza system from a historical perspective, difficulties of its application and implications for conservation. Subterranean Biology, 22, 1-26.

https://doi.org/10.3897/subtbiol.22.9759

Weckerly, F.W., 2012. Cave cricket exit counts: environmental influences and duration of surveys. Journal of Cave and Karst Studies, 74, 1-6. https://doi.org/10.4311/2011LSC0223

Yoder, J.A., Benoit, J.B., LaCagnin, M.J., Hobbs, H.H., 2011. Increased cave dwelling reduces the ability of cave crickets to resist dehydration. Journal of Comparative Physiology B, 181(5), 595-601. https://doi.org/10.1007/s00360-011-0555-5 